\title{
Varied student perception of e-text use among student populations in biology courses
}

\author{
Kerrie $\mathrm{McDaniel}^{1}$, and Jerry Daday ${ }^{2}$ \\ ${ }^{1}$ Department of Biology, Western Kentucky University, Bowling Green, KY \\ 2Department of Sociology, Executive Director Center for Innovative Teaching and Learning, Western Kentucky University, \\ Bowling Green, KY \\ For correspondence: Kerrie.mcdaniel@wku.edu
}

\begin{abstract}
The faculty in a biology department at a four-year public comprehensive university adopted e-texts for all 100 and 200 level biology courses with the primary motivation of reducing textbook costs to students. This study examines the students' perceptions of the e-texts adopted for these 100 and 200 level biology courses. An online questionnaire was developed and administered in multiple sections of six 100 and 200 level biology courses during the spring and fall semesters of 2014 to measure student perceptions of the e-texts used in these courses. Results suggest a bimodal distribution among our sample $(\mathrm{N}=2,152)$ of student participants. However, there are statistically significant and noteworthy exceptions to this general pattern. Black students reported a significantly higher satisfaction with e-texts compared to white students, and students repeating one of these courses reported significantly higher levels of satisfaction with the e-text compared to students taking the for the first time. Additionally, students with lower grade point averages (GPAs) preferred the e-text significantly more compared to those with higher GPAs. Further analyses reveal that the majority of student participants perceived the use of value-added technologies, such as e-homework, favorably.
\end{abstract}

Keywords: E-text, student perception, learning materials, repeating students, minority students

\section{Introduction}

Removing barriers to student success is a goal of most educators (Noguero, 2008; Paulson \& St. John, 2002). Financial concerns are factors that influence college choice and persistence in the United States. The cost of textbooks is of growing concern for educators at all levels and in all disciplines (Boczar et al., 2016). Electronic textbooks, or e-texts, are becoming more popular in the college classroom due to their lower cost (Baum et al., 2012). The tech savvy millennial generation is immersed in a mobile, digital world where information and feedback are a click away (El-Hussein \& Cronje, 2010; Rossing et al., 2012; Tapscott, 2008). The readily accessible, flexible e-text seems to be a good fit for this connected generation in college classrooms (Baker-Eveleth, et al., 2011; Cavanaugh, 2004; Clyde, 2005). Studies about student perceptions of e-texts are mixed. Although e-books are often selected for personal reading, many students prefer a printed text for the classroom (Lui, 2005; Daniel \& Willingham, 2012; Daniel \& Woody,2013; Woody et al., 2010). However, the role of the e-text is changing in the college classroom and past student perception data may not adequately reflect the deeper benefits of using these technologies (Daniel \&Woody, 2010; Koehler \& Mishra, 2010;Mueller et al,. 2008; Woody, et al., 2010). E-texts have expanded to include not only the written narrative and explanation but a cadre of adaptive learning tools, animations, simulations, measures of metacognition, and formative assessments (Gurung \& Daniel, 2005; Rhodes \& Rozell, 2015). These interactive tools (e-materials) have become a part of the e-text experience and may be discipline specific. The student perception of e-text juxtaposed against their perception of these learning tools 
has not been widely explored on college campuses, most especially in STEM (science, technology, engineering, and mathematics) fields.

\section{Aims of this study}

This study measures perceptions of e-texts among 2,152undergraduate students enrolled in multiple sections of six introductory level (e.g. 100 and 200 level) biology courses at a public comprehensive university in the Southeastern United States. In response to the demand for lower textbook costs and to meet the learning needs of the millennial generation, the Department of Biology at this university mandated the adoption of e-texts and e-materials for these six lower level courses. Enrollment in these courses obligated the purchase of the e-text and student access was granted through a sign-up process that allowed availability of the e-text on the first day of class. Digital materials (also referred to as e-materials) such as homework assignments, animations, and simulations were included in the e-text package at a cost much lower than the price of a printed book. This study measured student opinions and perceptions of using the e-text and e-materials in these courses and further disaggregated the results by various demographic characteristics within the student population.

\section{Methodology}

Perceptions of e-texts were measured using an online survey administered via Qualtrics to all students enrolled in multiple sections of six introductory level biology courses. Courses included introductory biology I \& II for majors and non-majors as well as anatomy and physiology I \& II courses. Student perception data not only provide information on what students think about e-texts but can also be used as an outcome to measure the learner's perceived achievement due to the use of e-texts. Student perception and satisfaction are viewed as learning outcomes or products of a student's mental evaluation of his/her achievement level (Keller \& Bless, 2008).

All students enrolled in these courses were invited to complete this online, anonymous, voluntary, self-administered questionnaire. Out of 3,462 students enrolled in these six courses during the calendar year of the study (2014), 2,152 participants completed the online survey instrument, for a participation rate of $62 \%$. The online instrument contained a variety of questions measuring student perceptions of the e-text and e-learning materials as well as demographic characteristics and selfreported academic achievement measures. Specific measures are discussed in greater detail below. A standard Likert scale was employed for a majority of the questions measuring the students' perceptions of the e-text and associated e-learning materials (Strongly Disagree $=1$; Disagree $=2$; Neither Agree nor Disagree $=3$; Agree $=4$; Strongly Agree $=5$ ). These indicators were compared across various demographic and academic performance indicators using cross-tabular analyses with corresponding chi-square tests for statistical significance. Table 1 provides descriptive statistics for all of the variables used in subsequent analyses. This research was approved by the Institutional Review Board at the university where this study was conducted.

\section{Results}

Table 1 reports the descriptive statistics of the variables used in the study. These included student perceptions of E-texts, student perception of E-learning materials and demographic characteristics. Of the 2,152 students who participate in the study, $80.3 \%$ were white, $12 \%$ were black and $7.6 \%$ reported another race/ethnicity. Around sixty-seven percent of students self-reported a grade point average (GPA) of 3.0 or above, $28.9 \%$ claimed a GPA between $2.00-2.99$, and $3.9 \%$ had GPAs below 2.00. Twenty-two percent of respondents were repeating the course in which they were enrolled. 
Table 1: Descriptive Statistics of Key Indicators/Variables (N=2,166)

\begin{tabular}{|c|c|c|c|c|}
\hline Perceptions of E-Text & Mean & St. Dev. & Min. & Max. \\
\hline I liked using an e-text compared to a paper text & 2.93 & 1.33 & 1 & 5 \\
\hline I preferred to print off the e-documents and use them & 3.21 & 1.22 & 1 & 5 \\
\hline $\begin{array}{l}\text { I would rather take a course that uses the e-learning } \\
\text { material than one that does not. }\end{array}$ & 3.05 & 1.16 & 1 & 5 \\
\hline $\begin{array}{l}\text { I would prefer to spend more for a printed textbook rather } \\
\text { than use an e-text }\end{array}$ & 2.93 & 1.29 & 1 & 5 \\
\hline \multicolumn{5}{|l|}{ Perceptions of E-Learning Materials } \\
\hline $\begin{array}{l}\text { The e-homework assignments helped me to learn the } \\
\text { material. }\end{array}$ & 3.58 & 1.14 & 1 & 5 \\
\hline $\begin{array}{l}\text { I liked having e-homework assignments so that I had } \\
\text { additional points to help my grade. }\end{array}$ & 4.3 & 1.00 & 1 & 5 \\
\hline $\begin{array}{l}\text { The e-homework forced me to spend time on biology } \\
\text { outside of class that I would not have spent on biology } \\
\text { otherwise. }\end{array}$ & 3.71 & 1.09 & 1 & 5 \\
\hline $\begin{array}{l}\text { I spent more time on homework than I would have in a } \\
\text { traditionally taught (without e-materials) course. }\end{array}$ & 3.27 & 1.06 & 1 & 5 \\
\hline Demographic Characteristics \& Academic Performance & $\%$ & St. Dev. & Min. & Max. \\
\hline Race/Ethnicity & & 0.59 & 1 & 3 \\
\hline - White & $80.3 \%$ & & & \\
\hline - $\quad$ Black & $12.1 \%$ & & & \\
\hline - Other & $7.6 \%$ & & & \\
\hline Repeating Students & & 0.23 & 0 & 1 \\
\hline - Yes & $22.6 \%$ & & & \\
\hline - No & $77.4 \%$ & & & \\
\hline Grade Point Average & & 1.14 & 1 & 5 \\
\hline - Less than 2.00 & $3.9 \%$ & & & \\
\hline - $\quad 2.00-2.49$ & $9.4 \%$ & & & \\
\hline - $\quad 2.50-2.99$ & $19.5 \%$ & & & \\
\hline - $\quad 3.00-3.49$ & $27.4 \%$ & & & \\
\hline - $\quad 3.50-4.00$ & $39.8 \%$ & & & \\
\hline
\end{tabular}

1=Strongly Agree; 2=Disagree; 3=Neither Agree nor Disagree; 4=Agree; 5=Strongly Agree

\section{Do Students Like E-texts?}

Data collected on student perceptions of the e-text used in these courses are mixed. Thirty-nine percent of students agreed and forty-three percent disagreed with the statement "I liked using an etext as compared to a paper text" (Table 2). This bi-modal response is also evident in questions measuring whether or not students would rather take a course that uses e-learning materials compared to one that does not (37\% agree versus $31 \%$ disagree) and whether or not student respondents would be willing to spend more on a physical textbook versus using an e-text (38\% agree versus $42 \%$ disagree). Moreover, nearly half (45\%) of the survey responses reported their preference to print off the e-documents and use them. Results clearly suggest that among the 2,152 respondents in this study, students have mixed perceptions about e-text use. 
Table 2: Student Perceptions of E-Texts and E-Learning Materials (\% of total respondents; $N=2,166$ )

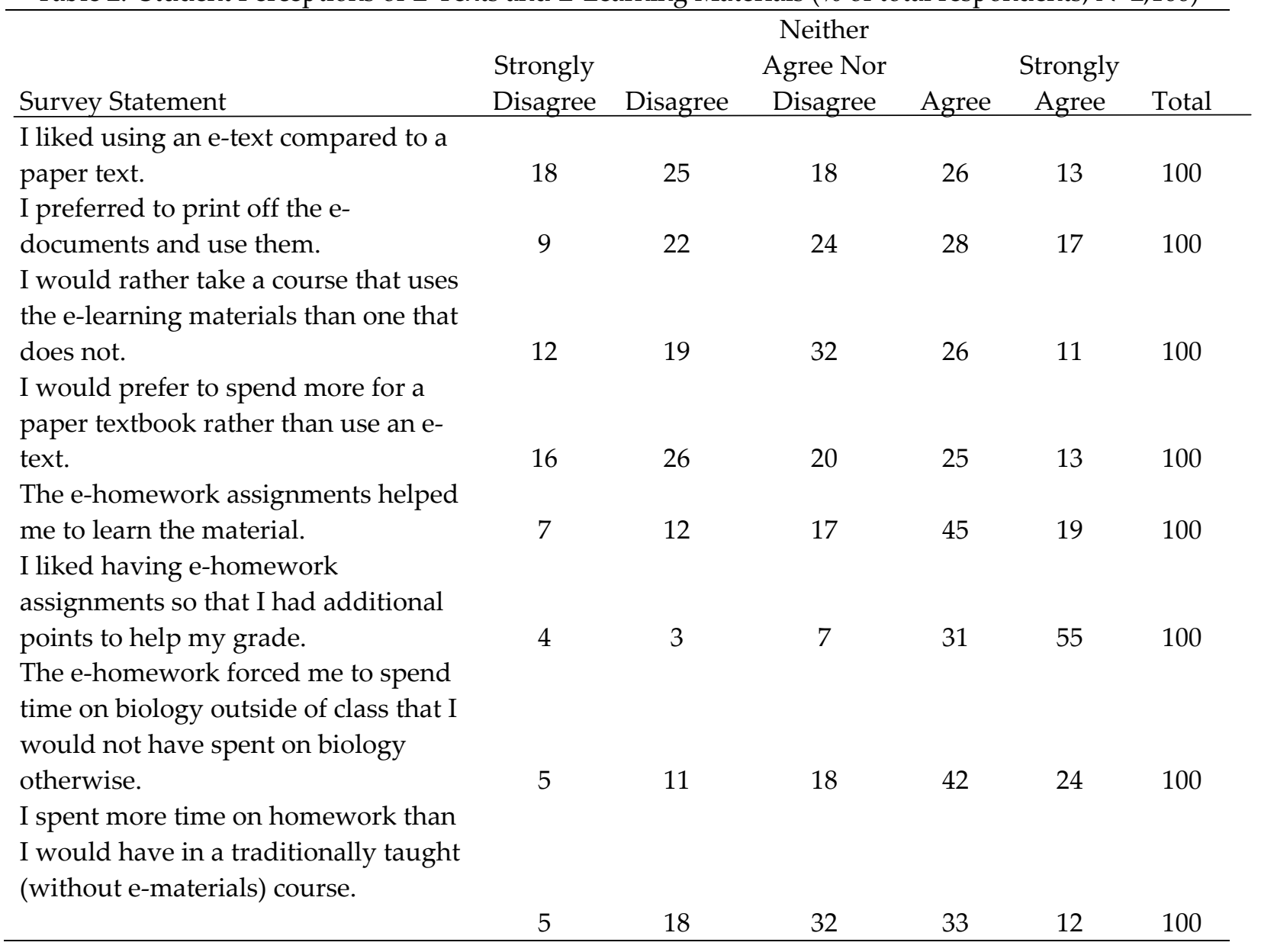

\section{E-Text Preference Among Demographics}

While mixed opinions about e-text use exist across all students in the sample, cross-tabular analyses with chi-square tests of statistical significance $(a=.05)$ reveal some important differences within the student population. For example, students with self-reported grade point averages (GPA) of less than 3.00 were significantly more likely to agree with the statement "I liked using the e-text compared to the paper text" compared to students with higher GPAs (Table 3). Students least satisfied with e-text were those with GPAs above 3.5. A similar trend is seen in data about perceptions of e-text and ematerial from students who were repeating one of the courses under investigation in this study. Students who were repeating the course in which they were enrolled reported liking the e-text compared to a paper text significantly more than those students who were taking the course for the first time (45\% to $39 \%$ ) (Table 4). Students taking the course a second time likely enrolled in the course in a previous semester at this university when the e-text and e-learning materials were not used.

Table 3: Relationship between Self-Reported GPA and Perception of E-text

\begin{tabular}{lcccccc}
\hline & $\begin{array}{c}\text { Strongly } \\
\text { Disagree } \\
\%\end{array}$ & $\begin{array}{c}\text { Disagree } \\
\%\end{array}$ & $\begin{array}{c}\text { Neither Agree } \\
\text { nor Disagree } \\
\%\end{array}$ & $\begin{array}{c}\text { Agree } \\
\%\end{array}$ & $\begin{array}{c}\text { Strongly } \\
\text { Agree } \\
\%\end{array}$ & $\begin{array}{c}\text { Total } \\
\%(\mathrm{~N})\end{array}$ \\
\hline GPA & 14 & 24 & 13 & 30 & 17 & $100(70)$ \\
$2.00-2.49$ & 17 & 16 & 22 & 28 & 17 & $100(173)$ \\
$2.50-2.99$ & 18 & 22 & 15 & 28 & 18 & $100(354)$ \\
$3.00-3.49$ & 18 & 25 & 16 & 26 & 14 & $100(501)$ \\
$3.50-4.00$ & 19 & 26 & 20 & 23 & 12 & $100(730)$ \\
\hline
\end{tabular}

Chi Sq. $=28.8 \quad \mathrm{p}<.05=$ Question: I liked using the e-text compared to a paper text. 
Table 4: Relationship between Repeating the Course and Perception of E-text

\begin{tabular}{lcclccl}
\hline & $\begin{array}{l}\text { Strongly } \\
\text { Agree } \\
\%\end{array}$ & $\begin{array}{c}\text { Disagree } \\
\%\end{array}$ & $\begin{array}{l}\text { Neither } \\
\text { Agree nor } \\
\text { Disagree } \\
\%\end{array}$ & $\begin{array}{c}\text { Agree } \\
\%\end{array}$ & $\begin{array}{l}\text { Strongly } \\
\text { Agree }\end{array}$ & $\begin{array}{l}\text { Total } \\
\%(\mathrm{~N})\end{array}$ \\
\hline $\begin{array}{l}\text { Repeating Course } \\
\text { Taking Course for First }\end{array}$ & 19 & 19 & 17 & 30 & 15 & $100(481)$ \\
Time & 18 & 25 & 18 & 25 & 14 & $100(1660)$ \\
\hline
\end{tabular}

Chi-Sq.=13.93 $\mathrm{p}<.01=$ Question: I liked using the e-text compared to a paper text.

Finally, results concerning perceptions about e-text usage show statistically significant differences between racial/ethnic groups. Among Black students, 58\% agreed with this statement about liking etexts compared to paper texts. This is significantly more support when compared to the $37 \%$ of white students and 39\% of students representing other racial or ethnic backgrounds who reported liking etexts compared to paper texts (Table 5).

Table 5: Relationship between Self-Reported Race and Perception of E-text

\begin{tabular}{|c|c|c|c|c|c|c|}
\hline \multicolumn{7}{|c|}{ Neither } \\
\hline & Strongly & & Agree Nor & & Strongly & \\
\hline & Disagree & Disagree & Disagree & Agree & Agree & Total \\
\hline Race & $\%$ & $\%$ & $\%$ & $\%$ & $\%$ & $\%(\mathrm{~N})$ \\
\hline White & 19 & 27 & 17 & 25 & 12 & $100(1698)$ \\
\hline Black & 9 & 17 & 16 & 34 & 24 & $100(253)$ \\
\hline Other & 14 & 21 & 26 & 24 & 15 & $100(160)$ \\
\hline
\end{tabular}

These results suggest that the mixed attitude toward e-texts evident in the whole sample of student respondents is by no means applicable across all subgroups, with lower performing students, blacks, and those repeating the course having significantly greater support for e-texts compared to other respective groups of students.

\section{Other Aspects of the E-text Implementation}

Although students with higher grade point averages (GPAs) tended to dislike the e-text when asked directly "I liked the e-text better than a paper text", their responses changed when they were specifically asked about value-added technologies such as digital homework assignments (ematerials) (Table 6). Eighty-nine percent of students with GPAs of 3.50-4.00 and $88 \%$ of students with GPAs of 3.00-3.49 reported liking e-homework assignments because of the additional points that these homework assignments provided to improve their overall grade in the course. In fact, this segment of the e-text implementation was one area where the vast majority of student respondents agreed. Seventy-eight percent of students with GPAs of less than 2.00, 76\% of students with GPAs between 2.00-2.49, and 83\% of students with GPAs between 2.50-2.99 also agreed with the statement that they liked e-homework assignments because it helped with their final grades. Additionally, $51 \%$ of students with the lowest GPAs (less than 2.00) found that the digital homework forced them to spend more time on the course than they would have without the assignments, and $51 \%$ of these students prefer courses that use e-learning material compared to courses that do not. 
Table 6: Significant Differences between GPA and Perceptions of E-text and E-Homework

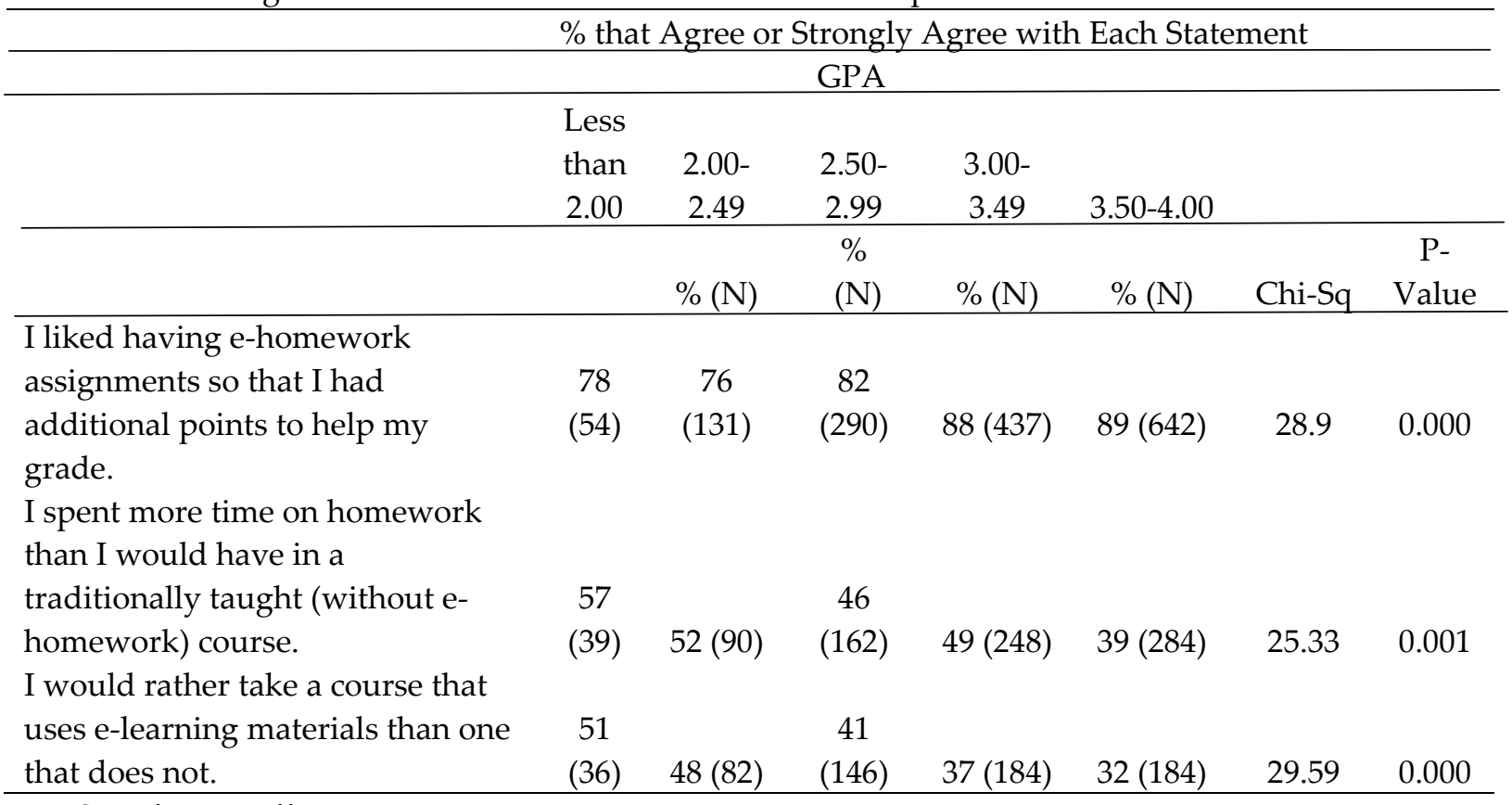

No Significant Differences

- The e-homework assignments helped me to learn the material.

- The e-homework forced me to spend time on biology outside of class that I would not have spent on biology otherwise.

- I preferred to print off the e-documents and use them.

- I would prefer to spend more for a paper textbook rather than use an e-text.

Similar to general e-text perceptions, important and significant differences were detected when these indicators measuring e-homework/e-materials preference were disaggregated by race (Table 7).As noted above, when the data were disaggregated by self-reported race, Black students liked the e-text $20 \%$ more than white students or students reporting their race as other $(p<.001)$ (Table 5). In addition, Black students reported being less willing to spend extra money on a paper text than white students indicating that financial strain may be an issue with these students (Table 7).

Table 7: Significant Differences between Race and Perceptions of E-text and E-Homework

\begin{tabular}{llllll}
\hline \multicolumn{7}{c}{$\begin{array}{l}\% \text { of Students who Agree or Strongly Agree with } \\
\text { Each Statement }\end{array}$} \\
\hline & $\begin{array}{l}\text { White } \\
\%(\mathrm{~N})\end{array}$ & $\begin{array}{l}\text { Black } \\
\%(\mathrm{~N})\end{array}$ & $\begin{array}{l}\text { Other } \\
\%(\mathrm{~N})\end{array}$ & $\begin{array}{l}\text { Chi- } \\
\text { Sq. }\end{array}$ & P-Value \\
\hline $\begin{array}{l}\text { I would rather take a course that uses the } \\
\text { e-learning material than one that does not. }\end{array}$ & $34(583)$ & $50(127)$ & $38(60)$ & 29.72 & 0.000 \\
$\begin{array}{l}\text { I would prefer to spend more money on a } \\
\text { paper textbook rather than use an e-text. }\end{array}$ & $40(671)$ & $31(80)$ & $34(55)$ & 16.86 & 0.001 \\
\hline
\end{tabular}

No Significant Differences

- The e-homework assignments helped me to learn the material

- I liked having e-homework assignments so that I had additional points to help my grade

- The e-homework forced me to spend time on biology outside of class that I would not have spent on biology otherwise.

- I spent more time on homework than I would have in a traditionally (no e-homework) taught course.

- I preferred to print off the e-documents and use them. 


\section{Discussion}

There are several contemporary issues in higher education in the United States that cross levels and discipline areas. These include topics such as increasing diversity, improving access to higher education, promoting retention and student engagement, and removing barriers to student learning. The burden of ever-increasing textbook costs is a hindrance to most of these important ideas (Lashley et al., 2017; Paulsen \& St. John, 2002; Provasnik \& Planty, 2008). E-text implementation is one intervention strategy to reduce the barrier of textbook cost while employing technology to improve pedagogy.

Lower cost is a major factor that influences student and instructor use of e-resources (Wook et al., 2013). From a pedagogical perspective, gains in student learning are the most important measure of e-text efficacy. Traditionally learning has been examined using grades or test scores which are cognitive metrics (Frith \& Kee, 2003). There is no evidence in the literature of differences in the letter grades of students who use e-texts versus paper texts, indicating that student achievement and the impact on learning are comparable for both (Murray \& Perez, 2011; Sheppard et al., 2008; RockinsonSzapkiw et al, 2013). However, in higher education students' perceptions about their learning may more accurately portray their overall understanding in a course (Ravia \& Baker, 2005). Student perceptions consider the attitudes about the topic and not just performance on exams, thus serving as valid learning outcomes (Chesebro \& McCroskey, 2000; Keller \&Bless, 2008). Therefore, student perceptions are important indicators in the overall measure of the success of e-text and e-material adoption (Chapman et al., 2016). Information about student perception of e-texts and e-materials along with the financial savingsare important factors to consider as more institutions move to adopt electronic materials.

\section{Do Students Like E-texts?}

When students were asked directly in this study if they "liked using an e-text as compared to a paper text", nearly an equal percentage of students agreed $(39 \%)$ and disagreed $(43 \%)$ with this statement (Table 2). This bi-modal distribution and mixed opinion mirror existing literature (Kang et al., 2009; Jamali, et al., 2010;Rockinson-Sxapkiw et al., 2013; Woody, et al., 2010). The mixed perceptions about e-text use are further viewed from the respondents' diverse ideas about whether they preferred courses that used e-text versus those that did not, or whether they were willing to spend more money on a printed copy of the text. In fact, similar to the literature, nearly half $(45 \%)$ of the survey responses reported their preference to print the e-documents and use them, implying that many of the students in the sample still prefer some physical document when reading a textbook (Austin \&Taylor, 2007). There does not seem to be a consensus about preference for using an electronic version of the textbook as compared to a print version, even with cost savings.

\section{E-Text Preference Among Demographics}

Although the overall perception of e-text use is mixed, some important differences among student populations emerged when cross-tabular analyses with chi-square tests of statistical significance $(a=$ .05) were applied to the data. Students with self-reported grade point averages (GPA) of less than 3.00 reported a higher, more favorable view of the e-text compared to students with GPAs above 3.5. These data align with other studies, and the difference may reflect variation in study habits and motivation (Bailey \& Ouwuegabuzie, 2002). Excellent students are intrinsically motivated and have better metacognitive awareness of what they need to study and which concepts they have already mastered (Butler \& Winne, 1995;Ch, 2006; Misch, 2002;Pintrich \& Zusho, 2002;Sobral, 2004) . These stronger students do not need additional experiences or formative assessments to perform well on exams and can become annoyed by what they perceive as "busy work". Contrarily, weaker students often do not know how to study and depend on external factors to construct context and meaning (Nicol \& Macfarlane-Dick, 2006). Interventions that offer learning strategies, study skills, and more formative assessment increase academic success for these students (McDaniel \& Daday, 2017; Soares 
et al., 2009). The e-text combined with the e-learning materials provide structure for how to study and offer context for content (Daniel \& Poole, 2009; Daniel \&Woody, 2013). Students with lower GPAs may prefer the interactive content and ease of access to specific items that e-texts offer (Doering, et al., 2012). Instead of perusing paper textbooks students can click on hyperlinks that take them to specific passages in the e-text. In addition, the e-text format provides anywhere,anytime learning without the burden of a hard copy textbook (Milrad \&Spikol,, 2007).

A second group of students who emerged with at statistically significant higher perception of e-text use was students who were repeating the course compared to students who were taking the course for the first time. Students who were unsuccessful in their first attempt of the course preferred the etext significantly more than students taking the course for the first time. Whether the e-learning materials and e-text offered the extra study tools needed to help these students maneuver through the course a second time or the students were motivated by access to more interactive content, there was a higher degree of satisfaction among these repeater students (Crede \& Kuncel, 2008; Nagaraju, 2004). The third group of students who reported significantly greater satisfaction with the e-text were Black students compared to the white students in our sample of college students. Among Black students, $50 \%$ reported liking e-texts compared to paper texts. Only $34 \%$ of white students reported a similar sentiment. Black students are of particular interest because they represent a group that often face challenges in academia and have a lower persistence rate than white counterparts (Anderson, 2008; Noguera, 2008; Harper, 2012). Study habits are a major factor influencing success of Black students in college (Wood \&Williams, 2013), and poor grades can lead to lower retention and graduation rates. Strategies that support better study habits and increased focus on course material may influence student success and lead to greater retention. Finding simple interventions that appeal to this population of students is important.

\section{Other Aspects of the E-text Implementation}

Today, modern e-texts are not just digital renditions of the paper text. Digital homework assignments provide opportunities for practice and formative assessment that may not be available in large classes that use more traditional printed textbooks. Interactive simulations and videos tied to the electronic books instruct in ways static textbooks cannot. The e-text combined with interactive materials and ehomework assignments offer more strategies for learning. All students surveyed had a positive perception of the e-learning materials that were coupled with the e-text. Even students with higher grade point averages (GPAs) that tended to dislike the e-text reported liking e-homework assignments because of the additional points that these homework assignments provided to help their grade in the course. These data were consistent with reports from students of all GPAs. It seems that all students, regardless of GPA, focus on point values and how these will influence their final averages in a course. For those students with the lowest GPAs (less than 2.00) the use of e-text and ematerial forced them to spend more time on the course than they would have without the assignments. The amount of time a student spends engaged with content (Time-on Task) has long been considered one of the tenants of effective education (Chickering \& Gamson, 1989). Strategies to increase the amount of time students spend working with content have been studied and shown to increase student learning (Bloom, 1974; Kareweit, 1984). E-texts and their accompanying assessments can increase the amount of time students spend on task by motivating students, increasing their time on task and making their studying more efficient (Chickering \& Ehrmann, 1996). Some research has shown that students find e-texts to be more entertaining and relevant to students' lives than print texts, which results in students spending more time on taskwhich can result in better comprehension of material in the lesson (Doering et al., 2012; Rockinson-Szapkiw, 2011;Wang \&Guthrie, 2004).

In addition to forcing students to spend more time on task, e-homework assignments provide valuable opportunities for formative assessment. Formative assessment is critical to increased student learning and is considered a major factor in excellent teaching (Costal et al., 2010; Hattie, 
2008; Lin \&Lai, 2013). Web-based homework systems with automatic grading allow students to receive immediate feedback to help students realize what they do not understand while not placing increased burden of grading on instructors (Jones, 2008). The formative assessment provided through the e-homework assignments allow students to self-regulate their learning and offer opportunities to practice and repeat assignments at their own pace at a time that is convenient (Vasilyeva, et al., 2008). Whether or not students realize that time on task and formative assessment are inherent to the e-text and e-learning materials, they do note the value of these assignments.

Black students not only had a positive perception of the e-text, but they also had a significantly higher perception of the e-materials than other students. It may be that black students view the e-text and ematerials as a learning package rather than simply a vehicle to deliver text. Requiring e-homework assignments necessitates that students engage in an educational routine where they can be successful, thus becoming invested in the learning experience (Kuh et al., 2008).

Okwumabua et. al, 2011 reported that black students had positive attitudes towards computers but a lower confidence in working online. Anderson and Adams (1992) have shown that black students prefer learning where cooperation, visual perception, symbolic expression and narrative are used to convey information. Black students thrive when content is provided in context in collaboration with others (Du et al., 2015). They are also less comfortable with exercises that require independence. The e-text, when coupled with the e-learning material, offers collaborative experiences, discussions/chats, visual ques, symbolic animations, and videos as well as practice that would appeal to these students (Reid et al., 2012). Although some interactive experiences, such as discussions and chats, could be provided by webpages or other vehicles of delivery, the central location of these immersive technologies with the e-text simplify their use.

The economy of e-texts seems to be an aspectof e-text use that was viewed positively by some black students. Data showed that black students were less willing to spend extra money on a paper text than white students indicating that financial strain may be an issue with these students. Paulsen \& St. John (2002) report that minority college students comprise a larger percentage of the low-income student population as compared to other groups of undergraduates. These low-income students list cost-related factors as major contributors to college choices. Black students were concerned about financial issues related to college and used economics not only to guide decisions about college choice, but also persistence (St. John et al., 2005). Interest in retention, especially of minority students, is at an all-time high (Kuh et al., 2008; Paulsen \& St. John, 2002; St John et al., 2005). Creating a first year learning experience that is satisfying and engaging for a diverse set of students is key to retention (Kuh et al., 2008). Yet many studies on retention focus on events and factors, such as homelife and socioeconomic status, that cannot be altered by the university. If black students report a high satisfaction with e-texts and they offer financial benefit, this intervention could play a small role in creating an early, positive college experience that could lead to persistence. This concept warrants more study.

\section{Conclusions}

On the surface, student perception of e-text use is mixed. When deeper analysis of the data are performed, specific subgroups are identified that have greater preference for e-texts and e-learning exercises. Three groups of students, who are often targeted by retention efforts, have positive perceptions of e-texts. These are black students, students with low GPAs, and students who are repeating a course due to an unsuccessful first attempt. All students surveyed have a positive perception of the value-added e-materials, such as e-homework assignments, that offer additional practice, reading comprehension, formative assessment, and additional points within final grades. Our empirical study shows satisfaction with e-text use depends on the subgroup of the student and how the e-text is used in the course. Faculty who choose to use e-texts as digital substitution of the 
printed words are missing out on the benefits of the electronic materials and are less likely to have student support its use. Students do like e-texts when they are used with thoughtful pedagogy to maximize learning in classroom (Chapman et. al., 2016; Yager et al., 2011). Motivation and economics are both factors that seem to influence satisfaction with e-texts. Implications of this study include implementation strategies for e-texts that involve thoughtfully incorporating value-added technologies (e-materials) into the curriculum that help students meet their learning goals. These may hold particular value for black students, students with low GPAs, and those repeating a course, which could possibly result in higher retention of these students. Additional studies should be conducted within the subgroups of students who most prefer e-texts to examine their interaction with e-text and to determine if retention is directly influenced by their use.

\section{Acknowledgements}

This project was funded by an internal grant from the Division of Extended Learning and Outreach at the university where this study was conducted. This research was approved by the Institutional Review Board at this same institution.

\section{References}

Anderson, J.A., \& Adams, M. (1992). Acknowledging the learning styles of diverse student populations: Implications for instructional design. In L. Border, \& N. Chism (Eds.), Teaching for diversity (pp. 19-33). San Francisco: Jossey Bass.

Anderson, E. (2008). Against the wall: Poor, young, black and male. Philadelphia: University of Pennsylvania Press.

Austin, B., \& Taylor, K. (2007). Reserves, electronic reserves and student copying practices at the University of Colorado Boulder: Is digital different? Journal of Interlibrary Loan, Documentary Delivery \& Electronic Reserves, 18(1), 17-32.

Bailey, P.D., \& Ouwuegbuzie, A.J. (2002). The role of study habits in foreign language courses. Assessment \& Evaluation in HigherEducation, 27(5), 463-473.

Baker-Eveleth, L. J., Miller, J. R., \& Tucker, L. (2011). Lowering business education cost with a custom professor-written online text. Journal of Education for Business, 86(4), 248-252.

Baum, S., Ma, J., \& Payea, K. (2012). Trends in public higher education: Enrollment, prices, student aid, revenues, and expenditures. Analysis Brief, College Board Advocacy \& Policy Center,(May).

Bloom, B.S. (1974). Rime and learning. American Psychologist, 29(9), 682-688.

Boczar, J., \& Pascual, L. (2017). E-books for the classroom and open access textbooks. Two ways to help students save money on Textbooks. The Serials Librarian, 72, 1-4.

Butler, D.L. Winne, P.H. (1995). Feedback and self-regulated learning: a theoretical synthesis. Review of Educational Research, 65(3): 245-281.

Cavanaugh, C., Gillan, K. J., Kromrey, J., Hess, M., \& Blomeyer, R. (2004). The effects of distance education on K-12 student outcomes: A meta-analysis. Learning Point Associates/North Central Regional Educational Laboratory (NCREL).

Chapman, J., Seeley, E., Wright, N., Lowell, G., \& Adams, L. (2016). An Empirical evaluation of broad ranging E-Text adoption with Recommendations for Improving Deployment Success for Students. E-Jounal of Business Education \& Scholarship of Teaching, 10(2), 114.

Chickering, A., \& Ehrmann, S. (1996). Implementing the seven principles: Technology as lever. AAHE Bulletin, 49, 3-6.

Ch, A.H., (2006). Effect of guidance services on study attitudes, study habits and acadmic achievement of secondary school students. Bulletin of Education \& Research, 28(1), 35-45.

Costal, D., Mullan, B.A., Kothe, E.J., \& Butow, F., (2010). A web-based formative assessment tool for Masters students: a pilot study. Computer \& Education, 54(4), 1248-1253.

Daniel, D., \& Poole, D.A. (2009). Learning for life: an ecological approach to pedagogical research. Perspectives on Psychological research. Perspectives on Psychological Science, 4(1), 91-96.

Daniel, D. B., \& Willingham, D. T. (2012). Electronic textbooks: why the rush?. Science, 335(6076), 1569-1571.

Daniel, D., \& Wood, W.D. (2013). E-textooks at what cost? Performance and use of electronic v. print text. Computers $\mathcal{E}$ Education, 62, 18-23.

El-Hussein, M. O. M., \& Cronje, J. C. (2010). Defining mobile learning in the higher education landscape. Educational Technology E Society, 13(3), 12-21.

Chesebro, J.L., \& McCroskey, J.C. (2000). The relationship between students' reports of learning and their actual recall of lecture material: a validity test. Communications Education, 49(3), 297-301.

Chickering, A.W. \& Gamson, Z. (1989). Seven principle for good practice in undergraduate education. Biochemical Education, 17(3), 140-141.

Crede, M., \& Kuncel, N.R. (2008). Study habits, skills and attitudes: The third pillar supporting collegiate academic performance. Perspective on Psychological Sciences, 3(6), 425-453.

Doering, T., Pereira, L., Kuechler, L., (2012). The use of E-textbooks in higher education: A Case Study. E-Leader Berlin (Germany). 
Du, J., Ge, X., Xu, J. (2015). Online collaborative learning activities: The perspectives of African American female students. Computers \& Education, 82, 152-161.

Frith, K.J., \& Kee, C. (2003). The effect of communication onnursing student outcomes in a web-based course. Journal of Nursing Education, 42(8), 350-358.

Gallien, L.B., \& Peterson, M. (2004). Instructing and Mentoring the African American College Student: Strategies for success in higher education. Boston, MA: Allyn and Bacon.

Hattie, J. (2008). Visible learning: A synthesis of over 800 meta-analyses relating to achievement. Routledge.

Harper, S.R. (2012). Black male student success in higher education: A report from the National Black Male College Achievement Study. Philadelphia: University of Pennsylvania Center for the Study of Race and Equity in Education.

Jamali, H.R., Nicholas, D., \& Rowland, I. (2010). Scholarly e-books: the views of 16,000 academics. New Information Perspectives, 61(1), 33-47.

Jones, C., (2008). Student perceptions of the impact of web-based homework on course interaction and learning introductory Accounting. The Accounting Educators Journal, 18, 15-28.

Kang, Y., Wang, M., \& Lin, R. (2009). Usability evaluation of e-books. Displays, 30(2), 49-52.

Keller, J. Bless, H. (2008). Flow and regulatory compatibility: An experimental approach to the flow model of intrinsic motivation. Personality Social Psychology Bulletin, 34:196-209.

Karweit, N. (1982). Time-on-task Reconsidered: Synthesis of Research on Time and Learning. Educational Leadership, 41(8), 3235.

Kuh, G.D., Cruce, T. M., Shoup, R., Kinzie, J., \& Gonyea, R.M. (2008). Unmasking the effects of student engagement on firstyear college grades and persistence. The Journal of Higher Education, 79(5),540-563.

Lashely, J., Cummings,-Sauls, R., Bennett, A.B., \& Lindshield, B. L. (2017) Cultivating Textbook Alternatives from the ground Up: One public university's sustainable model for open and alternative educational resource proliferation. The International Review of Research in Open and Distributed Learning, 18(4).

Linn, J.W., \& Lai, Y.C. (2013). Harnessing collaborative annotations on online formative assessments. Educational Technology $\mathcal{E}$ Society, 16(1), 263-274.

McDaniel, K. \& Daday, J. (2017). An Undergraduate Anatomy Lab Revision Success Story. HAPS Educator, 21(2), 8-18.

Milrad, M. \& Spikol, D. (2007). Anytime, anywhere learning supported by smart phones: experiences and results from the MUSIS project. Education Technology \& Society, 10(4), 62-70.

Mishra, P., Koehler, M. J., \& Henriksen, D. (2010). The 7 transdisciplinary habits of mind: Extending the TPACK framework framework towards 21st century learning. Educational Technology, 51(2), 22-28.

Misch, D.A. 2002. Andragogy and medical education: are medical student internally motivated to learn? Advances in Health Science Education Theory and Practice, 7:158-160.

Mueller, J., Wood, E., Willoughby, T., Ross, C., \& Specht, J. (2008). Identifying discriminating variables between teachers who fully integrate computers and teachers with limited integration. Computers \& Education, 51(4), 1523-1537.

Murray, M., \& Perez, J. (2011). E-textbooks are coming; are we ready? Issues in Informing Science \& Information Technology, 8, 4960.

Nagaraju, M.T.V. (2004). Study habits of secondary school students. New Delhi: Discovery Publishing House.

Noguera, P. (2008). The trouble with black boys... and other reflections on race, equity and the future of public education. San Francisco, CA: Jossey-Bass.

Paulsen, M.B., \& St. John, E.P.S., (2002) Social class and collge costs: Examing the financial nexus between college choice and persistence. The Journal of Higher Education,73(2),189-236.

Pintrich, P.R., Zusho, A. (2002). Student motivation and self-regulated learning in the college classroom. In : J.C. Smart and W.G. Tierney (Eds) Higher Education: Handbook of Theory and Research, Volume XVII, New York, Agathon Press.

Provasnik, S., \& Planty, M. (2008). Community colleges: special supplement to the condition of education 2008. Statistical analysis report. NCES 2008-033. National Center for Education Statistics.

Okwumabua, T.M., Walker, K.M., Hu, X, \& Watson, A. (2011). An exploration of African American students' attitudes toward online learning. Urban Education, 46, 241-250.

Reid, M.J., Flam, R., \& Tisiouris, F., (2012). New models for medical education : web-based conferencing to support HIV training in subSahara Africa. Telemedicine Journal and E-Health, 18(7), 565-569.

Rhodes, A. E., \& Rozell, T. G. (2015). A constructivist approach to e-text design for use in undergraduate physiology courses. Advances in physiology education, 39(3), 172-180.

Rockinson-Szapkiw, A., Holder, D., \& Dunn, R. (2011). Motivating students to learn: Is there a difference? Published in a Proceedings of Global Learn Asia Pacific. Pg. 235-239.

Rockinson-Szapkiw, A., Courdouff, J., Carter, K., \& Bennet, D. (2013). Electronic versus traditional print textbooks: A comparison study on the influence of university students' learning, Computers $\mathcal{E}$ Education, 63, 259-266.

Rossing, J. P., Miller, W. M., Cecil, A. K., \& Stamper, S. E. (2012). iLearning: The Future of Higher Education? Student Perceptions on Learning with Mobile Tablets. Journal of the Scholarship of Teaching and Learning, 12(2), 1-26.

Rovai, A., \& Baker, J. (2005). Gender differences in online learning. Quarterly Review of Distance Education, 6(1), 33-34.

Rovai, A., Wighting, M., Baker, J., \& Grooms, L. (2009). Development of an instrument to measure perceived cognitive, affective and psychomotor learning in traditional and virtual classroom higher education setting. The Internet and Higher Education, 12(1), 7-13.

Sheppard, J.A., Grace, J. L. \& Koch, E.J. (2008). Evaluating the electronic textbook: Is it time to dispense with the paper text? Teaching of Psychology, 35(1), 2-5. 
Soares, A.P., Guidsande, A.M., Almeida, L.S., \& Parama, F.M. (2009). Academic achievement in first-year Portuguese college students: The role of academic preparation and learning strategies. International Journal of Psychology, 44(3), $204-212$.

Sobral, D. (2004). What kind of motivation drives medical students' learning quests? Medical Education, 38:950-957.

St. John, E.P., Paulsen, M.B., \& Carter, D.F. (2005). Diversity, college costs, and postsecondary opportunity: An examination of the Financial nexus between college choice and persistence for African Americans and Whites. The Journal of Higher Education, 76(5), 545-569.

Tapscott, D. (2008). Grown Up Digital: How the Net Generation is Changing Your World HC. McGraw-Hill.

Vasileyeva, E., Pethenizkiy, M., \& De Bra, P. (2008). Adaptation of elaborated feedback in e-learning. In Adaptive Hypermedia and Adaptive Web-based Systems. (pp. 235-244). Springer Berlin, Heidleberg.

Wang, J.H., \& Guthrie, J.T. (2004). Modeling the effects of intrinsic motivation, extrinsic motivation, amount of reading, and past reading achievement on text comprehension between U.S and Chinese students. Reading Research Quarterly, 39, $162-186$.

Wood, L.J. \& Williams, R.C. (2013). Persistence factors for black males in the community college: An examination of background, academic, social and environmental variables. Spectrum: A Journal on Black Men, 1(2).

Wook, S., Michaels, S., \& Waterman, D. (2013). Print vs. electronic readings in college courses: Cost-efficiency and perceived learning. Internet and Higher Education, 21, 17-24.

Yager, S. and Szabo, Z. (2011). Using an e-Book to teach technology: Effects on student performance. SIGMIS-CPR'11. 